\title{
Unraveling the genetic complexity of Alzheimer disease with Mendelian Randomization
}

Sara Bandres-Ciga, PhD, and Faraz Faghri, MS

Neurol Genet 2019;5:e313. doi:10.1212/NXG.0000000000000313

Genome-wide association studies (GWASs) have changed the way we conceive human genetics and have led to the discovery of thousands of risk variants involved in disease etiology. However, despite tremendous advances made in understanding the genetic architecture underlying disease, there remains an underinvestigated component of risk, namely phenotypic traits that can predispose or protect individuals to disease. The availability of large amounts of GWAS data affords the opportunity to investigate the relationship between myriad traits. ${ }^{1}$

In the current issue of Neurology ${ }^{\circledR}$ Genetics, Raghavan et al. ${ }^{2}$ aim at determining the putative causal relationship between educational attainment and Alzheimer disease (AD). The authors use Mendelian Randomization, the gold standard for causality in genetic studies, as a statistical approach that uses genetic data in the form of SNPs to study whether an exposure exerts a causal effect in an outcome. This promising methodology sits at the interface between observational epidemiology and interventional trials and aims at addressing the question of whether an observational association between a risk or protective factor and a disease of interest is consistent with a causal effect by focusing usually only on genome-wide significant SNPs. One of the key strengths of this method is that it relies on genetic variants that are fixed at conception and remain constant over the lifespan of an individual and that are randomized during gametogenesis, which means that genetic variants are not associated with all the confounder factors that affect an observational study. ${ }^{3}$

In a simple way, SNPs genome-wide associated with a certain exposure modify the risk of that exposure, which in turn affects the disease of interest. Raghavan et al. not only consider SNP genome-wide related to educational attainment as instrumental variables but also use genetic regions surrounding individually associated SNPs to nominate genes that might contribute to the disease.

The authors identify a causal inverse relationship between educational attainment and $\mathrm{AD}$ and demonstrate that an increase of 4.2 years of educational attainment is associated with $37 \%$ reduction in $\mathrm{AD}$, exerting a notable protective effect. When focusing on individual loci, the authors identify 6 regions that significantly replicate the causal association and nominate the following genes: the leucine-rich repeat-containing 7 (LRCC7), the prostaglandin E receptor 3 (PTGER3), and the neuronal growth regulator precursor (NEGR1) genes as the main drivers of this relationship.

Mendelian Randomization has the potential to significantly contribute to our understanding of environmental and protective factors in Alzheimer disease; however, this method depends on assumptions, and the plausibility of these assumptions must be assessed. To verify the consistency of their findings, the authors perform a set of sensitivity analyses to account for confounding effects that
Correspondence

Dr. Bandres-Ciga

sara.bandresciga@nih.gov

\section{RELATED ARTICLE}

Genomic variation in educational attainment modifies Alzheimer disease risk

Page e310 
might be violating any core assumption. No evidence of reverse causation, horizontal pleiotropy, or heterogeneity is identified.

The reported findings should be interpreted in the context of existing evidence from other research studies using different designs, and clinical guidelines should not be elaborated uniquely based on Mendelian Randomization results. To make a definite conclusion that might be helpful from the clinical perspective to guide disease prevention, replicating these findings in non-European populations with variable educational background and experiences remains key.

\section{Author contributions}

Both authors contributed equally to the initial manuscript preparation, manuscript editing, and commentary.

\section{Study funding}

No targeted funding reported.

\section{Disclosure}

S. Bandres-Ciga and F. Faghri report no disclosures. Disclosures available: at Neurology.org/NG.

\section{References}

1. Buniello A, MacArthur JAL, Cerezo M, et al. The NHGRI-EBI GWAS Catalog of published genome-wide association studies, targeted arrays and summary statistics 2019. Nucleic Acids Res 2019;47:D1005-D1012.

2. Raghavan N, Vardarajan B, Mayeux R. Genomic variation in educational attainment modifies Alzheimer disease risk. Neurol Genet 2019;5:e310. doi: 10.1212/ NXG.0000000000000310

3. Davey Smith G, Hemani G. Mendelian randomization: genetic anchors for causal inference in epidemiological studies. Hum Mol Genet 2014;23: R89-R98. 


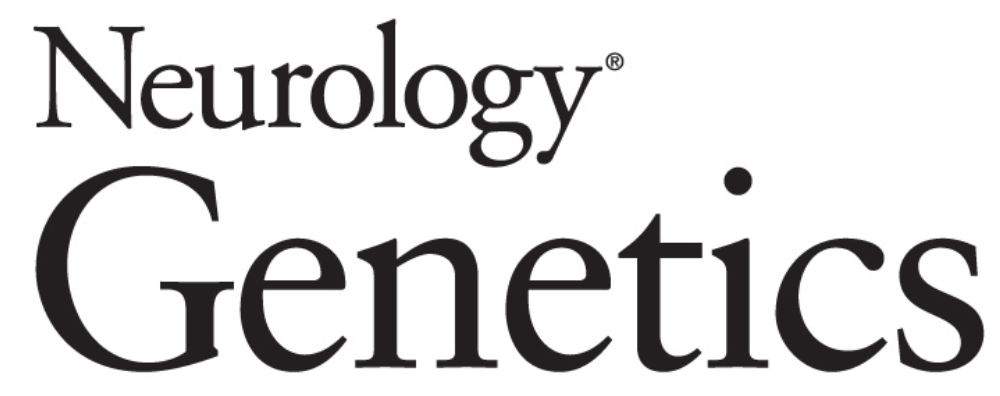

\title{
Unraveling the genetic complexity of Alzheimer disease with Mendelian Randomization Sara Bandres-Ciga and Faraz Faghri \\ Neurol Genet 2019;5; \\ DOI 10.1212/NXG.0000000000000313
}

This information is current as of March 7, 2019

\begin{abstract}
Updated Information \& Services

including high resolution figures, can be found at: http://ng.neurology.org/content/5/2/e313.full.html

References

This article cites 3 articles, 1 of which you can access for free at: http://ng.neurology.org/content/5/2/e313.full.html\#\#ref-list-1

Subspecialty Collections

This article, along with others on similar topics, appears in the following collection(s):

All Genetics

http://ng.neurology.org//cgi/collection/all_genetics

All Neuropsychology/Behavior Alzheimer's disease

http://ng.neurology.org//cgi/collection/alzheimers_disease

Permissions \& Licensing its entirety can be found online at:

http://ng.neurology.org/misc/about.xhtml\#permissions

Reprints

Information about ordering reprints can be found online: http://ng.neurology.org/misc/addir.xhtml\#reprintsus
\end{abstract}

http://ng.neurology.org//cgi/collection/all_neuropsychology_behavior

Information about reproducing this article in parts (figures,tables) or in

Neurol Genet is an official journal of the American Academy of Neurology. Published since April 2015, it is an open-access, online-only, continuous publication journal. Copyright Copyright @ 2019 The Author(s). Published by Wolters Kluwer Health, Inc. on behalf of the American Academy of Neurology.. All rights reserved. Online ISSN: 2376-7839.

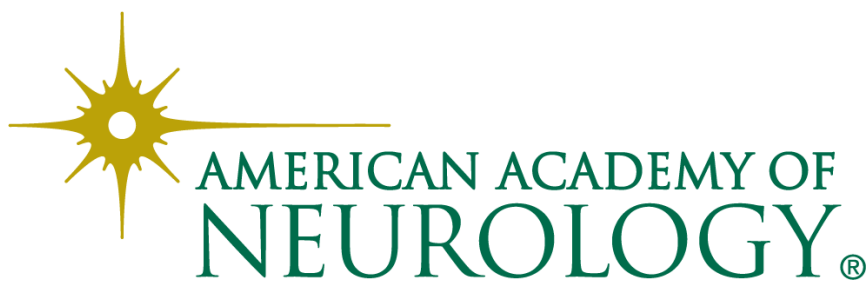

